Hydrol. Earth Syst. Sci., 12, 1257-1271, 2008

www.hydrol-earth-syst-sci.net/12/1257/2008/

(C) Author(s) 2008. This work is distributed under

the Creative Commons Attribution 3.0 License.

\title{
Vegetation dynamics and soil water balance in a water-limited Mediterranean ecosystem on Sardinia, Italy
}

\author{
N. Montaldo ${ }^{1}$, J. D. Albertson ${ }^{2}$, and M. Mancini ${ }^{3}$ \\ ${ }^{1}$ Dipartimento di Ingegneria del Territorio, Università di Cagliari, Cagliari, Italy \\ ${ }^{2}$ Department of Civil and Environmental Engineering, Pratt School of Engineering, Duke University, Durham, NC, USA \\ ${ }^{3}$ DIIAR, Politecnico di Milano, Milano, Italy
}

Received: 22 November 2007 - Published in Hydrol. Earth Syst. Sci. Discuss.: 31 January 2008

Revised: 29 July 2008 - Accepted: 16 September 2008 - Published: 25 November 2008

\begin{abstract}
Mediterranean ecosystems are commonly heterogeneous savanna-like ecosystems, with contrasting plant functional types (PFTs, e.g. grass and woody vegetation) competing for water. Mediterranean ecosystems are also commonly characterized by strong inter-annual rainfall variability, which influences the distributions of PFTs that vary spatially and temporally. An extensive field campaign in a Mediterranean setting was performed with the objective to investigate interactions between vegetation dynamics, soil water budget and land-surface fluxes in a water-limited ecosystem. Also a vegetation dynamic model (VDM) is coupled to a 3-component (bare soil, grass and woody vegetation) Land surface model (LSM). The case study is in Orroli, situated in the mid-west of Sardegna within the Flumendosa river basin. The landscape is a mixture of Mediterranean patchy vegetation types: trees, including wild olives and cork oaks, different shrubs and herbaceous species. Land surface fluxes, soil moisture and vegetation growth were monitored during the May 2003-June 2006 period. Interestingly, hydrometeorological conditions of the monitored years strongly differ, with dry and wet years in turn, such that a wide range of hydrometeorological conditions can be analyzed. The coupled VDM-LSM model is successfully tested for the case study, demonstrating high model performance for the wide range of eco-hydrologic conditions. Results demonstrate also that vegetation dynamics are strongly influenced by the inter-annual variability of atmospheric forcing, with grass leaf area index changing significantly each spring season according to seasonal rainfall amount.
\end{abstract}

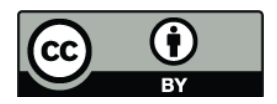

Correspondence to: N. Montaldo (nicola.montaldo@unica.it)

\section{Introduction}

Mediterranean semi-arid ecosystems are characterized by water-limited conditions. These ecosystems and the goods and services that they provide are increasingly threatened by the broad desertification processes produced by both natural (climate variation, fires, etc.) and human (deforestation, overgrazing, urbanization, pollution, fires, etc.) influences (e.g. Brunetti et al., 2002; Lelieveld et al., 2002; Moonen et al., 2002; Ventura et al., 2002; Ceballos et al., 2004).

These ecosystems are commonly heterogeneous savannalike ecosystems, with contrasting plant functional types (PFTs, e.g. grass, shrubs and trees) competing for water (Scholes and Archer, 1997; Ramirez-Sanz et al., 2000; Baldocchi et al., 2004; Fernandez et al., 2004; Williams and Albertson, 2004; Detto et al., 2006). Mediterranean water-limited ecosystems are also commonly characterized by strong interannual rainfall variability (e.g. Ramos, 2001; Cavazos and Rivas, 2004; Ceballos et al., 2004), which influences the PFT dynamics (Scholes and Archer, 1997; Fernandez et al., 2004).

Before making predictions for long-term (e.g. decade or hundred of years) scenarios related to climate change effects on these heterogeneous Mediterranean ecosystems (e.g. Vanrheenen et al., 2004; Manabe et al., 2004; Sanchez et al., 2007), there is the need to measure and model adequately land surface fluxes, soil moisture and vegetation dynamics for a sufficiently long time, including years characterized by different hydro-meteorological conditions. In this way the impact of the inter-annual variability of both the annual and seasonal hydro-meteorological conditions (e.g. rainfall) on vegetation dynamics and soil water balance of these ecosystems can be investigated.

Published by Copernicus Publications on behalf of the European Geosciences Union. 
Recent efforts of land surface models (LSM) and vegetation dynamic models (VDM) coupling have been achieved with the objective of modeling the dynamic interactions between land surface processes and vegetation dynamics (see, e.g. the review of Arora, 2002 and Montaldo et al., 2005). Current VDMs, and representations of ecophysiological processes (photosynthesis, respiration, allocation, phenology) are well reviewed in Arora (2002). Photosynthesis is the main biomass production term, and is a key process in vegetation growth modeling. The main approaches used for photosynthesis modeling are: 1) the biochemical approach of Farquar et al. (1980), which estimates the photosynthesis as the minimum of assimilation rates based on Rubisco, light, and transport capacity; 2) the constant light use efficiency (LUE) approach, which neglects the temporal dynamics of environmental stresses (e.g. drought); and 3) the carbon assimilation approach, which, in contrast, computes the photosynthesis from a maximum assimilation rate that is reduced by coefficients that express environmental stresses on leaf stomata opening.

A set of efforts for coupling VDMs and LSMs used ecological models that require a wealth of detailed information that is often unavailable in operational hydrological applications, mainly computing photosynthesis through the biochemical approach and complex versions of the carbon assimilation approach (Kemp et al., 1997; Calvet et al., 1998; Cox et al., 1999; Reynolds et al., 2000; Arora, 2003), while another set of efforts used mainly empirical and site-specific ecological models, computing photosynthesis through the LUE approach and simplified versions of the carbon assimilation approach (Haxeltine et al., 1996; Vertessy et al., 1996; Walker and Langridge, 1996; Gerten et al., 2004).

Attractive compromises are the coupled VDMs and LSMs of Cayrol et al. (2000) and Nouvellon et al. (2000). These models mainly differ in their photosynthesis computations, which are, however, both based on a carbon assimilation approach.

In the spirit of the models of Cayrol et al. (2000) and Nouvellon et al. (2000), Montaldo et al. (2005) developed a parsimonious and robust coupled model for grass dynamics only. In the model the VDM provides the grass leaf area index (LAI) evolution through time, and the LSM uses this to compute the land surface fluxes and update the soil water contents. They successfully tested the coupled model for two case studies of water-limited grass fields in California (USA) and North Carolina (USA). Even in such "simple" ecosystems characterized by only one PFT, they demonstrated the significant role of vegetation dynamics on soil water balance modeling in water-limited conditions, and the importance of including the VDM for correctly predicting land surface fluxes and soil water balance. Here we further develop the coupled model of Montaldo et al. (2005) for inclu- ding 3 cover types (bare soil, grass and woody vegetation) typical of more complex heterogeneous ecosystems, and test the model for a sufficient long data set including years characterized by different hydro-meteorological conditions.

The case study site is within the Flumendosa river basin on Sardinia, which is one of the regions of Italy most affected by water deficits. There is therefore an urgent need to exploit advanced observation and simulation technologies to provide a better understanding of the water balance regime for the entire island and for its major catchments. In this sense, the dam system of the Flumendosa river constitutes the water supply for much of southern Sardinia, including the island's largest city, Cagliari (about 350000 inhabitants in the urban area). The case study site is a natural patchy mixture of grass and woody vegetation, typical of Mediterranean ecosystems. During May 2003-June 2006 a micrometeorological tower has been installed and an extended field campaign has been conducted (Detto et al., 2006).

This paper addresses the following objectives:

1. pointing out the dynamics of land surface fluxes, soil moisture and vegetation cover for years with different hydro-meteorological conditions of the Sardinian heterogeneous ecosystem;

2. development of a 3-component (bare soil, grass and woody vegetation) coupled VDM-LSM for modeling land surface dynamics of a water-limited Mediterranean heterogeneous ecosystem;

3. assess the influence of key environmental factors on the vegetation dynamics for the different annual hydrologic conditions.

\section{The Orroli case study}

\subsection{The site}

The measurements were conducted at a site in Orroli, Italy, on the island of Sardinia $\left(39^{\circ} 41^{\prime} 12.57^{\prime \prime}\right.$ N, $9^{\circ} 16^{\prime} 30.34^{\prime \prime} \mathrm{E}$, $500 \mathrm{~m}$ a.s.1.). The measurement site covers an area of $\sim 1.5 \mathrm{~km}^{2}$ and sits on a gently sloping (approximately $3^{\circ}$ from NW to SE) plateau. The landscape is a patchy mixture of Mediterranean vegetation types: trees, mainly wild olive (Olea sylvestris) of height approximately 3.5-4.5 m, and a few cork oaks (Quercus suber) of height approximately 6$7 \mathrm{~m}$, shrubs (Asparagus acutifolius and Rubus ulmifolius), creepers of the wild olive trees (Crataegus azarolus and Smilax aspera), and $\mathrm{C} 3$ herbaceous (grass) species (Asphodelus microcarpus, Ferula comunis, Bellium bellidioides, Scolymus hispanicum, Sonchus arvensis, Vicia sativa, Euphorbia 
characias, Daucus carota, Bellis perennis; monocotyledons: Avena fatua, Hordeum murinum) that are present in live form only during wet seasons and reach heights of approximately $0.5 \mathrm{~m}$. The soil thickness varies from $15-40 \mathrm{~cm}$, bounded from below by a rocky layer of basalt, partially fractured. The root zone depth is coincident with the soil depth for these thin soils.

The climate at this site is typically Mediterranean - maritime, with a mean historical (1922-1992) annual precipitation of $690 \mathrm{~mm}$ (raingage data from the nearby village of Nurri), and mean historical monthly precipitations ranging between $103 \mathrm{~mm}$ in December and $12 \mathrm{~mm}$ in July (Fig. 1a). Furthermore, historical air temperature has a mean annual value of $13.9^{\circ} \mathrm{C}$, mean monthly values ranging between $23.1^{\circ} \mathrm{C}$ in July and $6.1^{\circ} \mathrm{C}$ in January (Fig. 1b).

\subsection{Field measurements}

An extended field campaign was carried out from May 2003 to June 2006, during which micrometeorological, soil moisture $(\theta)$, and vegetation dynamics measurements were conducted.

\subsubsection{Micrometeorological tower}

A $10 \mathrm{~m}$ tower was instrumented to measure land-atmosphere fluxes of energy, water, and carbon in addition to key state variables. The tower is surrounded by wild olive trees, grass and bare soils. It includes a Campbell Scientific CSAT-3 sonic anemometer and a Licor- $7500 \mathrm{CO}_{2} / \mathrm{H}_{2} \mathrm{O}$ infrared gas analyzer at $10 \mathrm{~m}$ above the ground to measure velocity, temperature and gas concentrations at $10 \mathrm{~Hz}$ for the estimation of latent heat (LE), and sensible heat fluxes $(H)$ through standard eddy-correlation methods (e.g. Brutsaert, 1982; Garratt, 1992). Half hourly statistics were computed and recorded by a 23X data logger (Campbell Scientific Inc., Logan, Utah). The effect of the gentle slope of the plateau was removed by an axis rotation (Detto et al., 2006) and the Webb-PearmanLeuning adjustment (Webb et al., 1980) was applied.

Three infrared transducers, IRTS-P (Apogee Instrument, accuracy of $0.3^{\circ} \mathrm{C}$ ) were used to measure the surface temperature $\left(T_{s}\right)$ of the different PFTs. One IRTS-P observed the skin temperature of a tree (wild olive) canopy at $3.5 \mathrm{~m}$ height above the ground and with a canopy view zenith angle of $\sim 70^{\circ}$, another observed either bare soil or grass (depending on the season) at $1.6 \mathrm{~m}$ above the ground with a canopy view zenith angle of $\sim 50^{\circ}$, and the third sensor was placed at a greater height $(10 \mathrm{~m}$ above the ground, view zenith angle of $\sim 40^{\circ}$ ) to observe a composite mixture of trees and soil or trees and grasses (depending on the season).

The incoming and outgoing shortwave and longwave radiation components were measured by a CNR-1 (Kipp \& Zonen) integral radiometer positioned at $10 \mathrm{~m}$ with a hemispherical field of view. Photosyntetically active radiation (PAR) was measured by the LI-190 Quantum Sensor (Licor).
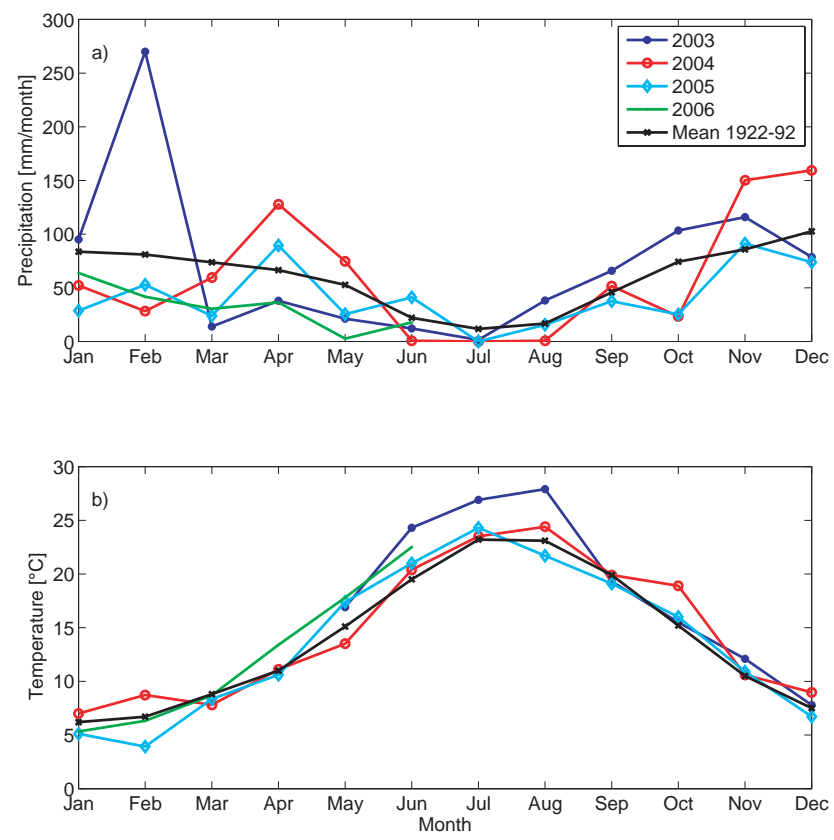

Fig. 1. Comparison between monthly mean historical (1922-1992) and observed (2003-2006) value of (a) precipitation and (b) temperature.

Soil heat flux $(G)$ was measured at two different locations close to the tower, one in an open patch ( $4 \mathrm{~m}$ from the tower) and one under a tree canopy of wild olive $(5.5 \mathrm{~m}$ from the tower), with thermopile plates, HFT3 (REBS), buried at $8 \mathrm{~cm}$ below the soil surface. Two thermocouples (per plate) were buried at 2 and $6 \mathrm{~cm}$, and one frequency domain reflectometer probe (FDR Campbell CS615) per plate was buried horizontally at $5 \mathrm{~cm}$, as needed to estimate changes in the stored energy above the plates (see HFT3 instruction manual edited by Campbell Sci.).

Precipitation was measured by an ARG100 (Environmental Measurements Limited) tipping bucket raingauge. Recorded precipitation time series are shown in Figs. 1 (monthly) and 2 (daily). Data gaps (13.5\% of the total half hour values) exist mainly due to power supply failures and maintenance operations. Rainfall and meteorological observations during the data gaps are filled with data of nearby stations located close to the town of Nurri $(\sim 5 \mathrm{~km}$ from the tower).

The two-dimensional footprint model of Detto et al. (2006), previously tested for this site, was used for interpreting eddy-correlation measurements in the context of the contributing land cover area. The footprint (source area) of eddy-correlation flux measurements changes in size and direction through time with the wind speed and stability of the flow. This variation can be exploited to sample various mixtures of the relative fractions of the different surface types. 


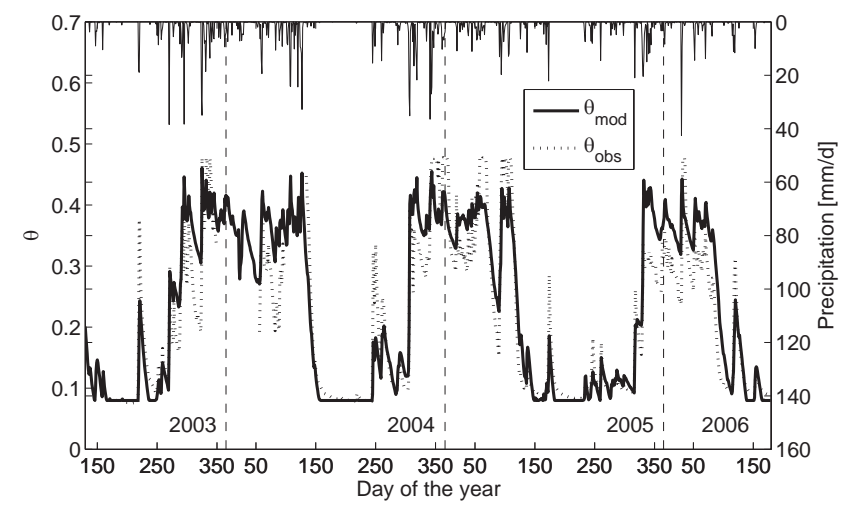

Fig. 2. Mean daily observed and modeled volumetric soil moisture $\theta$ time series ( soil depth $=25 \mathrm{~cm}$ ) for the Orroli case study. In the secondary ordinate axis daily precipitation values are reported.

The observed years were characterized by strongly contrasted hydro-meteorological conditions and offer a wide range of conditions understanding the ecosystem behavior. A comparison between monthly mean historical (1922-1992) and observed (2003-2006) precipitation and temperature is provided in Fig. 1. Spring and Summer 2003 were dry with low precipitation and high air temperature. The April and May months, which are key months for the grass growth in Sardinia, were particularly wet in 2004 (in particular the rain of April, $126 \mathrm{~mm}$, was almost double the mean historical, $67 \mathrm{~mm}$ ). Note also that air temperature was particularly high during the Spring 2006.

\subsubsection{Observations of soil moisture and vegetation dynamics}

Seven FDR probes (Campbell Scientific Model CS-616) were buried close to the tower (3.3-5.5 m away) to estimate the mean $\theta$ within the root-zone. Four of these were buried horizontally (two at $15 \mathrm{~cm}$ depth and two at $5 \mathrm{~cm}$ ) and three were installed vertically (i.e. average $0-30 \mathrm{~cm}$ ). The soil is mainly silt loam (19\% of sand, $76 \%$ of silt, $5 \%$ of clay) with a bulk density of $1.38 \mathrm{~g} / \mathrm{cm}^{3}$ and a porosity of $53 \%$. The FDR calibration $\left(\theta=2.456-7.135 \tau+6.701 ; \tau^{2}-1.884 \tau^{3}\right.$, with $\tau$ being the FDR probe output period in milliseconds) was made using gravimetric water content sampled (a total of 15 samples during the period of observation) near the probes over a wide range of soil moisture conditions $(0.08<\theta<0.52)$. The averaged (through an arithmetic mean across all the probes) $\theta$ time series are shown in Fig. 2 .

LAI was measured indirectly through a ceptometer (Accupar model PAR-80, Decagon devices inc., Washington USA), which measures the Photosynthetically Active Radiation (PAR) in the 400-700 nm waveband, and estimates the LAI from these readings (details in the instruction manual edited by Decagon devices inc.). In each campaign approximately 8 measurements of LAI were performed for each PFT
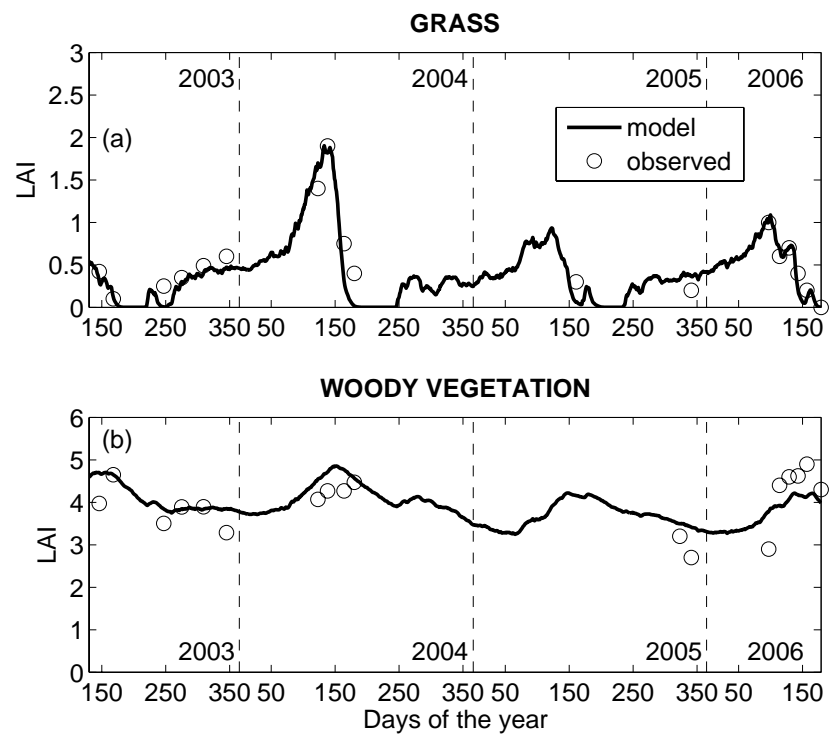

Fig. 3. Observed and modeled LAI of (a) grass and (b) woody vegetation for the Orroli case study.

around the field. Average LAI values of each campaign are reported in Fig. 3. LAI measurements were performed during the entire observation period, especially during the grass growth season (Fig. 3). LAI of the woody vegetation (Olea sylvestris that is the predominant woody vegetation type and which includes the creepers) changes moderately throughout the year (Fig. 3), whereas, the green leaf area of the herbaceous species increases rapidly with winter and spring precipitation and vanishes for the dry summer (Fig. 3).

Finally, specific leaf areas (leaf area divided by leaf dry biomass) of predominant grass $\left(=0.01 \mathrm{~m}^{2} \mathrm{gDM}^{-1}\right.$, mean of 3 samples covering an area of $1 \mathrm{~m}^{2}$ each and with a standard deviation of $0.0007 \mathrm{~m}^{2} \mathrm{gDM}^{-1}$ ) and woody vegetation $\left(=0.005 \mathrm{~m}^{2} \mathrm{gDM}^{-1}\right.$, mean of 3 samples covering an area of $1 \mathrm{~m}^{2}$ each and with a standard deviation of $0.001 \mathrm{~m}^{2} \mathrm{gDM}^{-1}$ ) species were measured directly (weighing the dry biomass). These values are needed to connect the biomass estimates of the vegetation dynamics model (discussed below) with the traditional LAI values, as reported in Fig. 3.

\subsection{Remote sensing images}

For estimating the fraction of vegetation cover distribution of the site, two multispectral high spatial resolution $(2.8 \mathrm{~m} \times 2.8 \mathrm{~m}$ per pixel) Quickbird satellite images (DigitalGlobe Inc.) were acquired (Day of Year (DOY)=220, 2003 and DOY $=138,2004$ ) (Fig. 4). The two images depict the contrast between the spring (bottom) and summer (top) land cover present surrounding the field site. The top image characterizes the land cover when the soil moisture conditions are very dry $(\theta \approx 0.08)$ and green herbaceous cover is absent such as is typical in the Sardinian Summer. The bottom image 
depicts the land cover conditions after a long wet period $(\theta \approx 0.4$, Fig. 2) particularly propitious for plant growing, so that the bare soil was nearly absent while the flourishing grasses reached their maximum growth in those days.

The 6S model of Vermote et al. (1997) was used to correct the images for atmospheric effects. Details are provided in Detto et al. (2006). A supervised classification scheme based on the parallepiped algorithm (Richards, 1999) allows for distinguishing "woody-vegetation" (WV) from "non-woodyvegetation" (NWV, i.e. bare soil or grass according to the time period) from the images. The widely used normalized difference vegetation index (NDVI) (e.g. Gamon et al., 1995; Carlson and Ripley, 1997; Scanlon et al., 2002) was computed from the surface reflectance values averaged over ranges of wavelengths in the visible red and NIR regions of the spectrum. Following Detto et al. (2006), in each map pixel the fraction of woody vegetation cover is estimated as $\mathrm{NDVI}_{i j} / \mathrm{NDVI}_{\text {max }}$, where $\mathrm{NDVI}_{i j}$ is the NDVI value of a particular grid cell and $\mathrm{NDVI}_{\max }$ is the spatial maximum of the particular NDVI map. The NDVI/NDVI $I_{\max }$ map of the field around the tower (the tower is in the center of the map) for the DOY=220, 2003 is computed (Fig. 5a). Note that $\mathrm{NDVI} / \mathrm{NDVI}_{\max }$ values of $\mathrm{WV}$ pixels are greater than 0.6 , so that the color bar of the Fig. 5a is modified for a better contrast of the WV pixels.

The combined use of the footprint model (see Sect. 2.2.1) and the high-resolution satellite images allows us to interpret the eddy-correlation observed surface flux. Indeed, the source area of each PFT and bare soil to the measured flux are distinguished using the methodology of Detto et al. (2006). Figure $5 \mathrm{~b}$ reports the frequency distribution of the fraction of WV cover $\left(f_{f p, W V}\right)$ in the footprint of the micrometeorological observations for the entire dataset. We note that $f_{f p, W V}$ is mainly in the range of $0.1-0.22$ with the peak of the distribution close to 0.15 .

\section{The 3-component coupled land surface - vegetation dynamic models}

In this section we describe the land surface model (LSM) and the vegetation dynamics model (VDM). The essence of this modeling coupling is that the VDM provides the leaf area index (LAI) evolution through time for each PFT, which are then used by the LSM for computations of the energy partitioning between soil and vegetation. Model parameters are defined in Table 1, and model meteorological inputs are in Table 2.

\subsection{The land surface model}

The LSM predicts dynamics of water and energy fluxes at the land surface on a half-hour time step. It is derived from the LSM of Montaldo and Albertson (2001) including three components in the land surface: bare soil and two vegetated

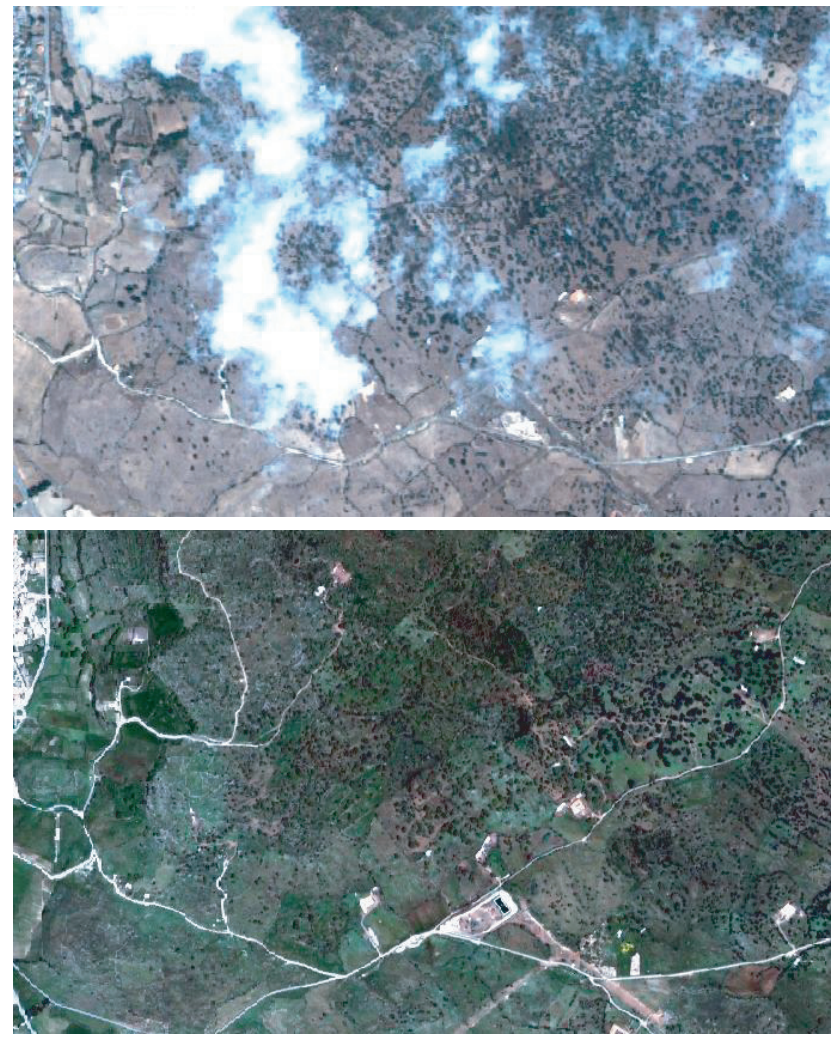

Fig. 4. Two multispectral high spatial resolution $(2.8 \mathrm{~m} \times 2.8 \mathrm{~m}$ per pixel) Quickbird satellite images (DigitalGlobe Inc.) of (top panel) DOY=220, 2003 and (bottom panel) DOY=138, 2004.

components (e.g. grass and WV). The states of surface temperature and moisture are estimated through the force-restore method (Noilhan and Planton, 1989; Montaldo and Albertson, 2001). The root zone supplies the bare-soil and vegetation with soil moisture for evapotranspiration, and controls the infiltration and runoff mechanisms. The base of the root zone represents the lower boundary of the LSM. Equations for surface temperature and three components $(H, G$ and the net radiation, $R_{n}$ ) of the energy balance are the same as Noilhan and Planton (1989) and are reported in Table 3. They are applied separately for each land cover component, so that the model predicts the energy balance distinctly for each land cover component.

In the unsaturated soil the Clapp and Hornberger (1978) relationships are used to describe the non-linear dependencies of volumetric soil moisture $(\theta)$ and hydraulic conductivity $(k)$ on the matric potential $(\psi)$. The soil water balance equation of the root zone is computed by

$$
\begin{aligned}
\frac{d \theta_{r z}}{d t}= & \frac{1}{d_{r z}}\left(f_{b s} I_{b s}+f_{v, W V} I_{w v}+f_{v, g r} I_{g r}-f_{b s} E_{b s}-\right. \\
& \left.f_{v, W V} E_{w v}-f_{v, g r} E_{g r}-q_{D}\right)
\end{aligned}
$$

where $\theta_{r z}$ is the soil moisture of the root zone, $d_{r z}$ is the root zone depth, $I_{b s}$ is the infiltration rate on bare soil, 
Table 1. Model parameters (VDM-LSM model) for the Orroli site.

\begin{tabular}{|c|c|c|c|c|}
\hline \multirow[t]{2}{*}{ Parameter } & \multirow[t]{2}{*}{ Description } & \multicolumn{2}{|c|}{ Value* } & \multirow[t]{2}{*}{ Source } \\
\hline & & Grass & WV & \\
\hline \multicolumn{5}{|c|}{ LSM-VDM parameters } \\
\hline$r_{s, \min }\left[\mathrm{s} \mathrm{m}^{-1}\right]$ & Minimum stomatal resistance & 100 & 280 & L1995 \\
\hline$T_{\min }\left[{ }^{\circ} \mathrm{K}\right]$ & Minimum temperature & 272.15 & 272.15 & L1995 \\
\hline$T_{\text {opt }}\left[{ }^{\circ} \mathrm{K}\right]$ & Optimal temperature & 295.15 & 292.15 & L1995 \\
\hline$T_{\max }\left[{ }^{\circ} \mathrm{K}\right]$ & Maximum temperature & 313.15 & 318.15 & L1995 \\
\hline$\theta_{w p}[-]$ & Wilting point & 0.08 & 0 & D2006 \\
\hline$\theta_{\lim }[-]$ & Limiting soil moisture for vegetation & 0.20 & 0.15 & D2006 \\
\hline$\omega\left[\mathrm{HPa}^{-1}\right]$ & Slope of the $f_{3}$ relation & 0.01 & 0.01 & J1976 \\
\hline \multicolumn{5}{|c|}{ Only VDM parameters } \\
\hline$c_{g}\left[\mathrm{~m}^{2} \mathrm{gDM}^{-1}\right]$ & Specific leaf areas of the green biomass in growing season & 0.01 & 0.005 & obs. \\
\hline$c_{d}\left[\mathrm{~m}^{2} \mathrm{gDM}^{-1}\right]$ & Specific leaf areas of the dead biomass & 0.01 & 0.005 & cal. \\
\hline$k_{e}[-]$ & PAR extinction coefficient & 0.5 & 0.5 & E2002 \\
\hline$\xi_{a}[-]$ & Parameter controlling allocation to leaves & 0.6 & 0.55 & cal. \\
\hline$\xi_{s}[-]$ & Parameter controlling allocation to stem & & 0.1 & A2005 \\
\hline$\xi_{r}[-]$ & Parameter controlling allocation to roots & 0.4 & 0.35 & Cal. \\
\hline$\Omega[-]$ & Allocation parameter & 0.8 & 0.8 & A2005 \\
\hline$m_{a}\left[\mathrm{~d}^{-1}\right]$ & Maintenance respiration coefficients for aboveground biomass & 0.012 & 0.0009 & A1984 \\
\hline$m_{s}\left[d^{-1}\right]$ & Maintenance respiration coefficients for stem & & 0.0004 & cal. \\
\hline$d_{s}\left[d^{-1}\right]$ & Death rate of stem biomass & & 0.0001 & cal. \\
\hline$g_{a}[-]$ & Growth respiration coefficients for aboveground biomass & 0.22 & 0.45 & $\mathrm{~N} 2000$ \\
\hline$m_{r}\left[\mathrm{~d}^{-1}\right]$ & Maintenance respiration coefficients for root biomass & 0.007 & 0.002 & cal. \\
\hline$g_{r}[-]$ & Growth respiration coefficients for root biomass & 0.1 & 0.1 & cal. \\
\hline$Q_{10}[-]$ & Temperature coefficient in the respiration process & 2.5 & 2 & A2001 \\
\hline$d_{a}\left[\mathrm{~d}^{-1}\right]$ & Death rate of aboveground biomass & 0.023 & 0.0045 & cal. \\
\hline$d_{r}\left[\mathrm{~d}^{-1}\right]$ & Death rate of root biomass & 0.005 & 0.005 & cal. \\
\hline$k_{a}\left[\mathrm{~d}^{-1}\right]$ & Rate of standing biomass pushed down & 0.23 & 0.35 & cal. \\
\hline \multicolumn{5}{|c|}{ Only LSM parameters } \\
\hline$z_{o m, v}[\mathrm{~m}]$ & Vegetation momentum roughness length & 0.05 & 0.5 & D2006 \\
\hline$z_{o v, v}[\mathrm{~m}]$ & Vegetation water vapor roughness length & $z_{o m} / 7.4$ & $z_{o m} / 2.5$ & B1982 \\
\hline$z_{\text {om }, b s}[\mathrm{~m}]$ & Bare soil momentum roughness length & \multicolumn{2}{|c|}{0.015} & D2006 \\
\hline$z_{o v, b s}[\mathrm{~m}]$ & Bare soil water vapor roughness length & \multicolumn{2}{|c|}{$z_{\text {om }} / 10$} & B1982 \\
\hline$\theta_{S}[-]$ & saturated soil moisture & \multicolumn{2}{|c|}{0.53} & Cal. \\
\hline$b[-]$ & slope of the retention curve & \multicolumn{2}{|c|}{8} & C1978 \\
\hline$k_{S}[\mathrm{~m} / \mathrm{s}]$ & saturated hydraulic conductivity & \multicolumn{2}{|c|}{$5 \times 10^{-6}$} & C1978 \\
\hline$\left|\psi_{S}\right|[\mathrm{m}]$ & air entry suction head & \multicolumn{2}{|c|}{0.79} & C1978 \\
\hline$d_{r z}[\mathrm{~m}]$ & root zone depth & \multicolumn{2}{|c|}{0.25} & obs. \\
\hline
\end{tabular}

A1984: Amthor (1984); A2001: Aber and Melillo (2001); A2005: Arora and Boer (2005); B1982: Brutsaert (1982); C1978: Clapp and Hornberger (1978); D2006: Detto et al. (2006); E2002: Eagleson (2002); J1976: Jarvis (1976); L1995: Larcher (1995); N2000: Nouvellon et al. (2000); obs.: approximate value from field observations; cal.: value from model calibration.

* for the vegetation related parameters two values are provided for grass and WV, while for the soil parameters one value is provided only.

$I_{w v}$ and $I_{g r}$ are the throughfall rates infiltrating into the soil covered by WV and grass respectively, $q_{D}$ the rate of drainage out of the bottom of the root zone, $E_{b s}$ is the rate of bare soil evaporation, $E_{w v}$ and $E_{g r}$ are the rates of transpiration of WV and grass respectively, $f_{v, W V}$ is the fraction of green WV area per unit of ground area, $f_{v, g r}$ is the fraction of green grass vegetation area per unit of ground area, and $f_{b s}\left(=1-f_{v t, W V}-f_{v t, g r}\right)$ is the frac- tion of bare soil, where $f_{v t, W V}$ and $f_{v t, g r}$ are the total WV and grass vegetation area (including dead vegetation), respectively. The total evapotranspiration, ET, is equal to $f_{b s} E_{b s}+f_{v, W V} E_{w v}+f_{v, g r} E_{g r}$. As in the original Noilhan and Planton (1989) model, the throughfall rate is modeled through a balance equation of the intercepted water by the canopy reservoir (its capacity is a function of the LAI), which produces throughfall when the reservoir is saturated. 

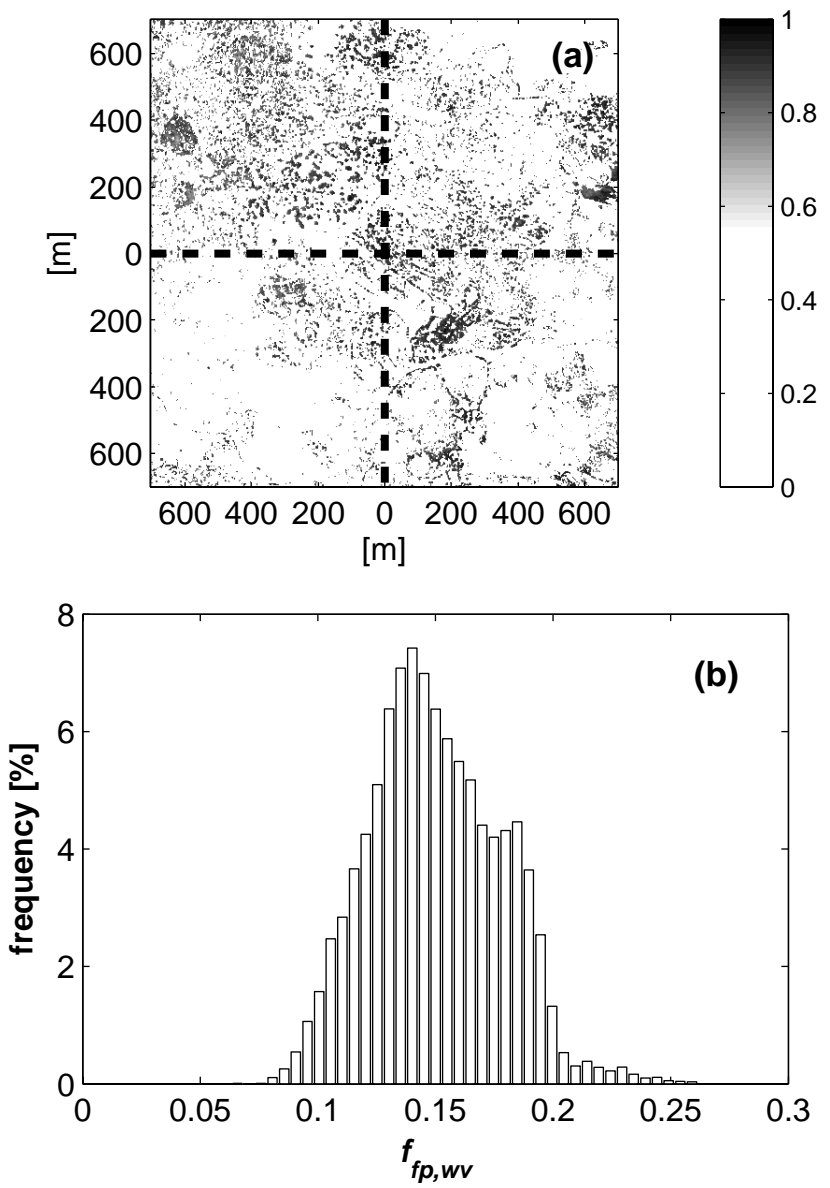

Fig. 5. (a) The map of NDVI/NDVI $I_{\max }$ of WV of the field around the tower (the tower is in the center of the map) determined from the Quickbird image for DOY=220, 2003; note that NDVI/NDVI $\max$ values of $\mathrm{WV}$ pixels are greater than 0.6 , so that the color bar is modified for a better contrast of the WV pixels. (b): The histogram of the fraction of WV cover $\left(f_{f p, W V}\right)$ in the footprint of the micrometeorological observations for the entire dataset the time series.

The $q_{D}$ rate is estimated using the unit head gradient assumption (Albertson and Kiely, 2001), which is justified for the case study because it allows to account for both the downward flux into the partially fractured basalt and the lateral water flux due to the field slope (see Sect. 2.1).

In the original model of Montaldo and Albertson (2001) the infiltration rate was computed through a saturation excess mechanism, which is not suitable for this case study, typically characterized by Hortonian overland flow due to the thin soil and the semi-arid conditions (e.g. Chow et al., 1988, p. 129). Hence, the infiltration model was updated for including the infiltration excess mechanism. According to this mechanism, the actual infiltration rate of the $x$ th land cover type, $I_{x}$, is taken as the minimum of the rainfall rate (or throughfall in the case of vegetated components) and an
Table 2. Model meteorological inputs.

\begin{tabular}{lll}
\hline Input description & Symbol & Unit \\
\hline Precipitation & $\Pi$ & $\mathrm{m} / \mathrm{s}$ \\
Air temperature & $T_{a}$ & ${ }^{\circ} \mathrm{C}$ \\
Wind velocity & $u$ & $\mathrm{~m} / \mathrm{s}$ \\
Incoming shortwave radiation & $R_{\text {swin }}$ & $\mathrm{W} / \mathrm{m}^{2}$ \\
Air relative humidity & $\mathrm{RH}$ & $\%$ \\
Photosynthetically & & \\
active radiation & PAR & $\mathrm{mmol} \mathrm{s}^{-1} \mathrm{~m}^{-2}$ \\
\hline
\end{tabular}

Table 3. Equations of $H, R_{n}, G$ and surface temperature.

\begin{tabular}{ll}
\hline \multicolumn{1}{c}{ Equations } \\
\hline heat flux & $\begin{array}{l}H=\rho_{a} c_{p} C_{H} u\left(T_{s}-T_{a}\right) \\
\text { with } C_{H} \text { the heat transfer coefficient } \\
R_{n}=R_{\text {swin }}(1-\alpha)+\varepsilon\left(R_{\text {lwin }}-\sigma T_{s}^{4}\right) \\
\text { Nith } R_{\text {lwin }} \text { estimated by Eq. }(6.10) \\
\text { of Brutsaert }(1982), \alpha \text { albedo, } \varepsilon \text { emissitivity } \\
\text { and } \sigma \text { the Stefan-Boltzmann constant }\end{array}$ \\
$\begin{array}{l}\text { Soil } \\
\text { heat flux } \\
\text { temperature }\end{array}$ & $\begin{array}{l}G=R_{n}-H-\mathrm{LE} \\
\frac{d T_{s}}{d t}=C_{T} G-\frac{2 \pi}{\tau}\left(T_{s}-T_{a}\right) \\
\text { with } T_{2} \text { the mean } T_{s} \text { value over one day } \tau, \\
\text { and } C_{T} \text { the soil thermal coefficient } \\
\frac{d T_{2}}{d t}=\frac{1}{\tau}\left(T_{s}-T_{2}\right)\end{array}$ \\
\hline
\end{tabular}

infiltration capacity, $I^{*}$, based on the Philip's infiltration equation

$I^{*}=\frac{1}{2} S_{s} t_{k}^{-\frac{1}{2}}+A k_{s}$

where $t_{k}$ is the time since the onset of infiltration, $S_{s}$ is the sorptivity, and $A$ is a constant. $S_{S}$ and $A$ are estimated by Sivapalan et al. (1987) using expressions in terms of soil properties and the root zone moisture content at the start of the storm event. For eliminating $t_{k}$, the Milly (1986) approach (based on the time compression approximation) is used, so that $I^{*}$ only depends on the cumulative infiltration (in addition to $S_{S}$ and $A$ ).

$E_{w v}$ and $E_{g r}$ are estimated distinctly using the PenmanMonteith equation (e.g. Brutsaert, 1982, p. 224) for each PFT. The Shuttleworth and Wallace (1985) approach extended the Penman-Monteith equation to two sources (vegetation and soil), we adopt an approach that extends the Penman-Monteith equation to three distinct cover types (bare soil, grass, woody vegetation). The canopy resistances that account for environmental stresses are estimated fol- 
lowing Montaldo et al. (2005), and are described in Appendix A and are clearly different for each PFT. The aerodynamic resistances are estimated as function of wind velocity through the transfer coefficient for water vapor, $C_{E}$ (Garratt, 1999, Eq. 3.57), according to the MoninObukhov similarity theory. $C_{E}$ and the heat transfer coefficient $\left(C_{H}\right.$, used in $H$ estimates, see Table 3$)$ account for atmosphere stability (Garratt, 1999, Eq. 3.47), with the flux profile functions for stable and unstable conditions estimated through equations (3.35), (3.36), (3.39) and (3.40) of Garratt (1999).

Finally, the actual rate of bare soil evaporation is determined by

$E_{b s}=\alpha\left(\theta_{g}\right) E_{p}$

where $E_{p}$ is the potential evaporation estimated by the Penman equation (e.g. Brutsaert, 1982, Eq. 10.15, 10.16 and 10.19), $\theta_{g}$ is the surface soil moisture, and $\alpha\left(\theta_{g}\right)$ is a ratelimiting function, estimated by the polynomial function of Parlange et al. (1999).

\subsection{The vegetation dynamic model}

The VDM computes change in biomass over time from the difference between the rates of biomass production (photosynthesis) and loss, such as occur through respiration and senescence (e.g. Larcher, 1995; Cayrol et al., 2000). The VDM distinguishes WV and grass components, and is adapted from Montaldo et al. (2005), who derived a VDM for grass species starting from the Nouvellon et al. (2000) model. Since we are modeling semi-arid regions, we assume that water availability is the major factor limiting plant growth, thus neglecting nutrient limitations (Larcher, 1995; Mouillot et al., 2001).

In the VDM of WV, four separate biomass states (compartments) are tracked: green leaves $\left(B_{g}\right)$, stem $\left(B_{s}\right)$, living $\operatorname{root}\left(B_{r}\right)$, and standing dead $\left(B_{d}\right)$. The biomass $\left[\mathrm{g} \mathrm{DM} \mathrm{m}^{-2}\right]$ components are simulated by ordinary differential equations integrated numerically at a daily time step (Nouvellon et al., 2000; Cayrol et al., 2000; Arora and Boer, 2005; Montaldo et al., 2005):

$$
\begin{aligned}
& \frac{d B_{g}}{d t}=a_{a} P_{g}-R_{g}-S_{g} \\
& \frac{d B_{s}}{d t}=a_{s} P_{g}-R_{s}-S_{s} \\
& \frac{d B_{r}}{d t}=a_{r} P_{g}-R_{r}-S_{r} \\
& \frac{d B_{d}}{d t}=S_{g}-L_{a}
\end{aligned}
$$

\begin{tabular}{|c|c|c|}
\hline $\begin{array}{l}\text { Ecophysiological } \\
\text { term }\end{array}$ & Equations & Source \\
\hline Photosynthesis & $\begin{array}{l}P_{g}=\varepsilon_{P}(\mathrm{PAR}) f_{\mathrm{PAR}} \mathrm{PAR} \frac{1.37 r_{a}+1.6 r_{c, \min }}{1.37 r_{a}+1.6 r_{c}} \\
\varepsilon_{P}(\mathrm{PAR})=a_{0}+a_{1} \mathrm{PAR}+a_{2} \mathrm{PAR}^{2} \\
f_{\mathrm{PAR}}=1-e^{-k_{e} \mathrm{LAI}}\end{array}$ & M2005 \\
\hline Allocation & $\begin{array}{l}\text { For woody vegetation: } \\
a_{a}=\frac{\xi_{a}}{1+\Omega\left[2-\lambda-f_{1}(\theta)\right]} \\
a_{s}=\frac{\xi_{s}+\Omega(1-\lambda)}{1+\Omega\left[2-\lambda-f_{1}(\theta)\right]} \\
a_{r}=\frac{\xi_{r}+\Omega\left(1-f_{1}(\theta)\right)}{1+\Omega\left[2-\lambda-f_{1}(\theta)\right]} \\
\xi_{a}+\xi_{s}+\xi_{r}=1 ; \lambda=e^{-k_{e} \mathrm{LAI}} \\
\text { For grass } \\
a_{a}=\frac{\xi_{a}+\Omega \lambda}{1+\Omega\left[1+\lambda-f_{1}(\theta)\right]} \\
a_{r}=\frac{\xi_{r}+\Omega\left(1-f_{1}(\theta)\right)}{1+\Omega\left[1+\lambda-f_{1}(\theta)\right]} \\
\xi_{a}+\xi_{r}=1\end{array}$ & A2005 \\
\hline Respiration & $\begin{array}{l}R_{g}=m_{a} f_{4}(T) B_{g}+g_{a} a_{a} P_{g} \\
R_{S}=m_{s} f_{4}(T) B_{g}+g_{s} a_{s} P_{g} \\
R_{r}=m_{r} f_{4}(T) B_{r}+g_{r} a_{r} P_{g} \\
f_{4}(T)=Q_{10}^{\frac{T_{m}}{10}} \\
\text { with } T_{m}=\text { mean daily temperature }\end{array}$ & $\begin{array}{l}\text { C1986; } \\
\text { N2000; } \\
\text { M2005 } \\
\text { M2005 }\end{array}$ \\
\hline Senescence & $\begin{array}{l}S_{g}=d_{a} B_{g} \\
S_{S}=d_{S} B_{S} \\
S_{r}=d_{r} B_{r}\end{array}$ & $\begin{array}{l}\text { N2000; } \\
\text { M2005 }\end{array}$ \\
\hline Litterfall & $L_{a}=k_{a} B_{d}$ & $\begin{array}{l}\text { N2000; } \\
\text { M2005 }\end{array}$ \\
\hline
\end{tabular}

where $P_{g}$ is the gross photosynthesis, $a_{a}, a_{s}$ and $a_{r}$ are allocation (partitioning) coefficients to leaves, stem and root
Table 4. Equations and references of the terms in Eqs. (4)-(7).

C1986: Charles-Edwards et al. (1986); C2000: Cayrol et al. (2000b); N2000: Nouvellon et al. (2000); A2005: Arora and Boer (2005); M2005: Montaldo et al. (2005).

compartments $\left(a_{a}+a_{s}+a_{r}=1\right), R_{g}, R_{s}$ and $R_{r}$ are the respiration rates from leaves, stem and root biomass, respectively, $S_{g}, S_{s}$ and $S_{r}$ are the senescence rates of leaves, stem and root biomass, respectively, and $L_{a}$ is the litter fall.

The key term of the VDM, $P_{g}$, is computed using the approach of Montaldo et al. (2005) (Table 4). Starting from a simplified form of Fick's law applied to gas exchange in plants (Larcher, 1995; Lambers et al., 1998) and the Nouvellon et al. (2000) model, Montaldo et al. (2005) derived a simplified expression that estimates $P_{g}$ by mainly the PAR, and other routinely monitored variables (wind velocity, and air humidity and temperature, Table 4 and Appendix A). Other terms of the VDM are computed as in Montaldo et al. (2005), while the photosynthesis allocation to leaves, stem and roots is estimated by adapting the new approach of Arora and Boer (2005) (see this reference for a deeper discussion 
of the allocation coefficients behavior). The equations for the photosynthesis allocation estimates and the other terms of Eqs. (4)-(7) are described in Table 4 and model parameters are defined in Table 1.

The VDM of grass distinguishes only three biomass compartments (green leaves, roots and standing dead) and the biomass components are simulated using Eqs. (4), (6) and (7), respectively.

Leaf area index values are estimated from the biomass through linear relationships (Hanson et al., 1988; Nouvellon et al., 2000; Arora, 2003; Montaldo et al., 2005):

$\mathrm{LAI}=c_{g} B_{g}$

$\mathrm{LAI}_{d}=c_{d} B_{d}$

where LAI and $\mathrm{LAI}_{d}$ are the green and dead leaf area index of the $x$ th land cover type, respectively. The total leaf area index $\mathrm{LAI}_{t}$ is then estimated by

$\mathrm{LAI}_{t}=\mathrm{LAI}+\mathrm{LAI}_{d}$

3.3 Coupling the land surface model and the vegetation dynamic model

The LSM is then coupled with the VDM. VDM provides LAI values of WV and grass daily by Eq. (8), which are then used by the LSM for computing the evapotranspiration estimate (e.g. Eq. A1), energy flux and the soil water content in the root-zone by Eq. (1) at a half-hour time step. Indeed, while the daily VDM time step is appropriate for predicting vegetation cover dynamics and, at the same time, it allows less computation efforts, a sub-hourly time resolution is necessary for the LSM for predicting correctly the energy balance and surface temperature dynamics, which are highly dependent to diurnal variations. The LSM provides soil moisture and aerodynamic resistances to the VDM.

Leaf area index values are also used for updating the total fraction of vegetation cover, $f_{v t}$, of the generic PFT values through (Montaldo et al., 2005):

$f_{v t}=f_{v} \frac{\mathrm{LAI}_{t}}{\mathrm{LAI}}$

with $f_{v}$ the fraction of vegetation of the generic PFT.

\section{Results}

The coupled VDM-LSM is tested for predicting energy balance terms, soil moisture and LAI of both PFTs. Since data of several years are available, the model is calibrated with data from the two first hydrologic years (2003/04 and 2004/05), and then validated for the last hydrologic year $(2005 / 06)$. Note that LAI observations of 2005 are unfortunately not available (Fig. 3).

An analysis of the influence of key environmental factors on the vegetation dynamics interannual variability is finally provided.
Table 5. Statistical index of model performance.

\begin{tabular}{lllll}
\hline \multirow{2}{*}{$\begin{array}{l}\text { Index } \\
\text { Term }\end{array}$} & \multicolumn{2}{c}{ RMSE } & \multicolumn{2}{c}{ Mean error } \\
& Calibration & Validation & Calibration & Validation \\
\hline ET $[\mathrm{mm} / \mathrm{d}]$ & 0.626 & 0.430 & 0.069 & 0.021 \\
$\theta$ & 0.051 & 0.049 & 0.005 & 0.023 \\
$R_{n}[\mathrm{~mm} / \mathrm{d}]$ & 1.636 & 1.136 & 0.333 & 0.083 \\
$H[\mathrm{~mm} / \mathrm{d}]$ & 1.250 & 0.924 & 0.454 & 0.216 \\
$G[\mathrm{~mm} / \mathrm{d}]$ & 0.874 & 0.338 & 0.001 & 0.127 \\
\hline
\end{tabular}

\subsection{The coupled VDM-LSM}

The VDM-LSM coupled model was calibrated for the case study, comparing observed and simulated time series of the energy balance terms, $\theta$, and LAI through a trial-and-error procedure. Note that for comparing micrometeorological observations and model predictions of LE and $H$ we used the time varying footprint of the tower for estimating the fraction of WV cover (see Sect. 2.2.1), while for the soil moisture budget we used the fraction of land covers of the field monitored by the soil moisture probes $\left(f_{v, W V}=0.25\right.$ and $\left.f_{v, g r}=0.6\right)$. The Table 1 reports the calibrated parameter values. Coefficients of the leaf photochemical efficiency, $\varepsilon_{P}$, of the photosynthesis model are the same of Montaldo et al. (2005) $\left(a_{0}=0.007, a_{1}=-0.0205, a_{2}=0.019\right.$ with PAR expressed in $\mathrm{kW} / \mathrm{m}^{2}$ ). Note that all parameters are held constant throughout the study period. In Table 5 statistical index (root mean square error, rmse, and mean error) for model performance evaluation are reported for both calibration and validation periods.

Observed surface temperature, a key indicator of the energy balance, is well simulated for the three land cover components (Fig. 6). The accuracy of the coupled model for predicting energy balance terms is demonstrated by the results shown in Figs. 7, 8 and 9 and statistical results in Table 4. Net radiation $\left(R_{n}\right)$, sensible heat flux $(H)$ and soil heat flux $(G)$ dynamics are all well estimated on the whole (Fig. 7). The scatter plots of Fig. 8 are on a daily time scale.

Daily ET rates and cumulative ET are shown in Fig. 9, and a scatter plot of ET time series are in Fig. 8c. Cumulative ET, which is important for soil water balance purposes, is well simulated (Fig. 9b), ending with the $95 \%$ of the observed total ET.

Root zone soil moisture dynamics are also sufficiently well simulated (Fig. 2) with rmse (root mean square error) of 0.054 for the calibration period and 0.053 for the validation period (Table 5). The model does not capture well the daily soil moisture variability of individual probes during several rain events, but well predicts soil moisture average dynamics. However, note that main inaccuracy of soil moisture modeling are during Summer rain events because measured soil moisture peaks do not agree with the rain gage input. 

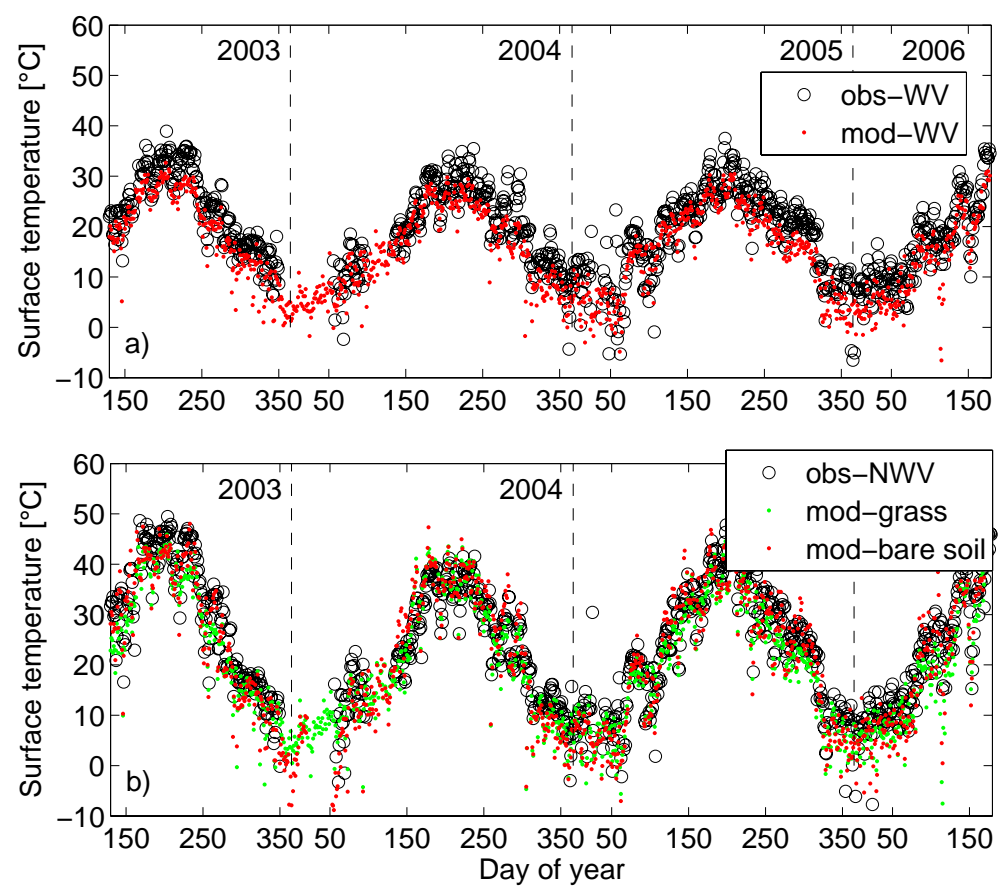

Fig. 6. Mean daily observed and modeled time series of surface temperature of (a) WV cover and (b) NWV cover (bare soil or grass or both depending the period of the year).
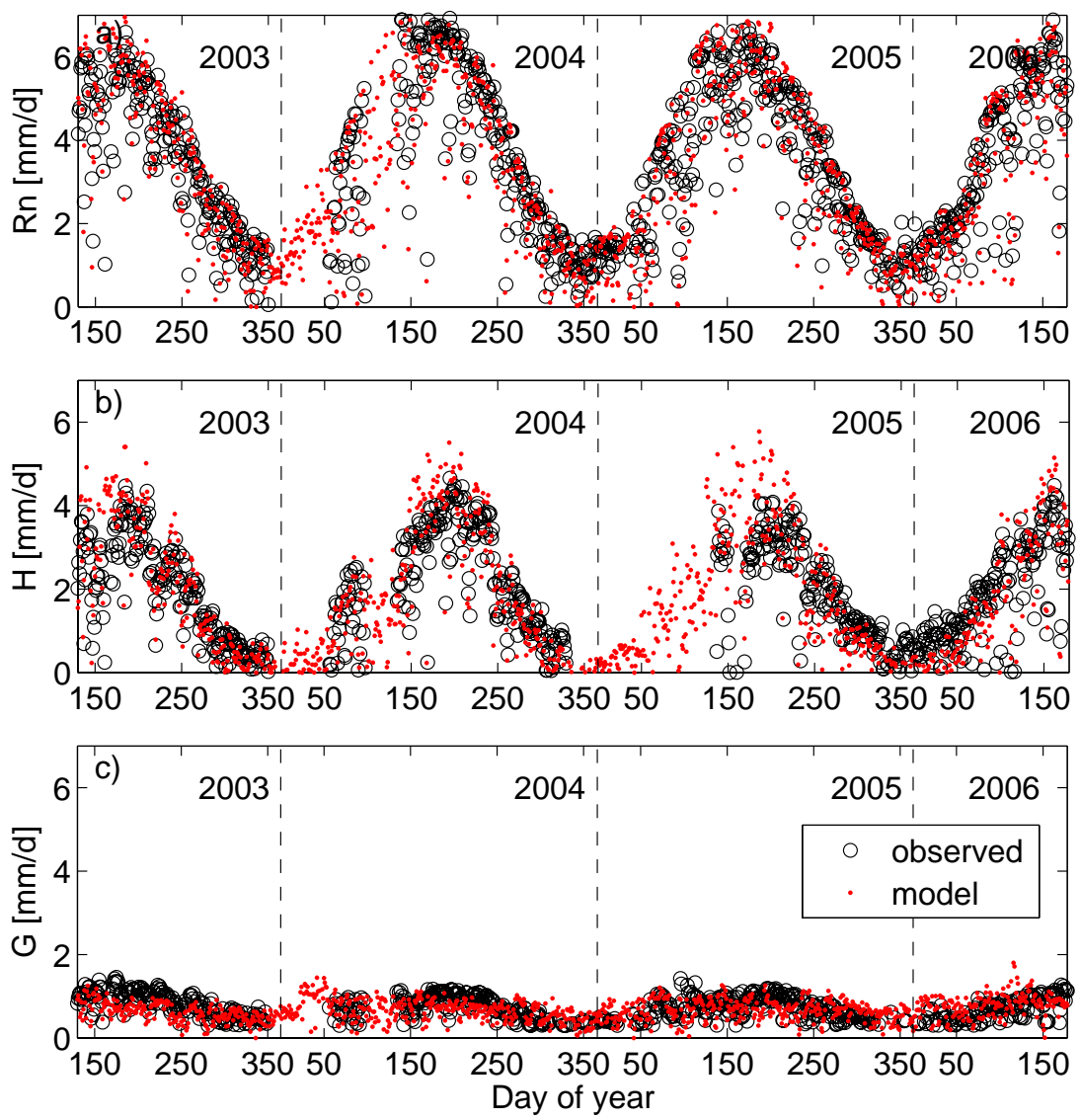

Fig. 7. Mean daily observed and modeled time series of (a) net radiation $\left(R_{n}\right)$, (b) sensible heat flux $(H)$ and $(\mathbf{c})$ ground heat flux $(G)$. 

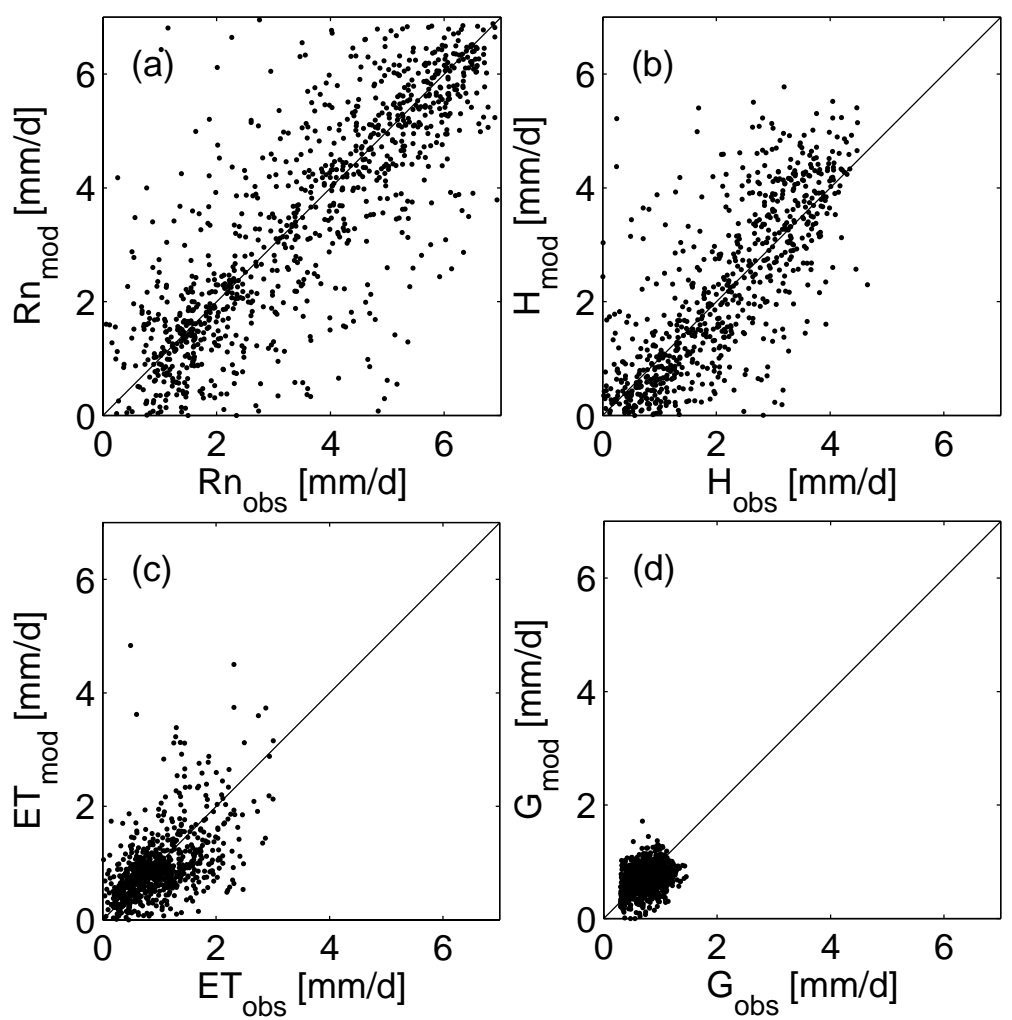

Fig. 8. Mean daily values of observed vs. modeled time series of (a) net radiation $\left(R_{n}\right)$, (b) sensible heat flux $(H)$, evapotranspiration $($ ET) and (d) ground heat flux $(G)$.

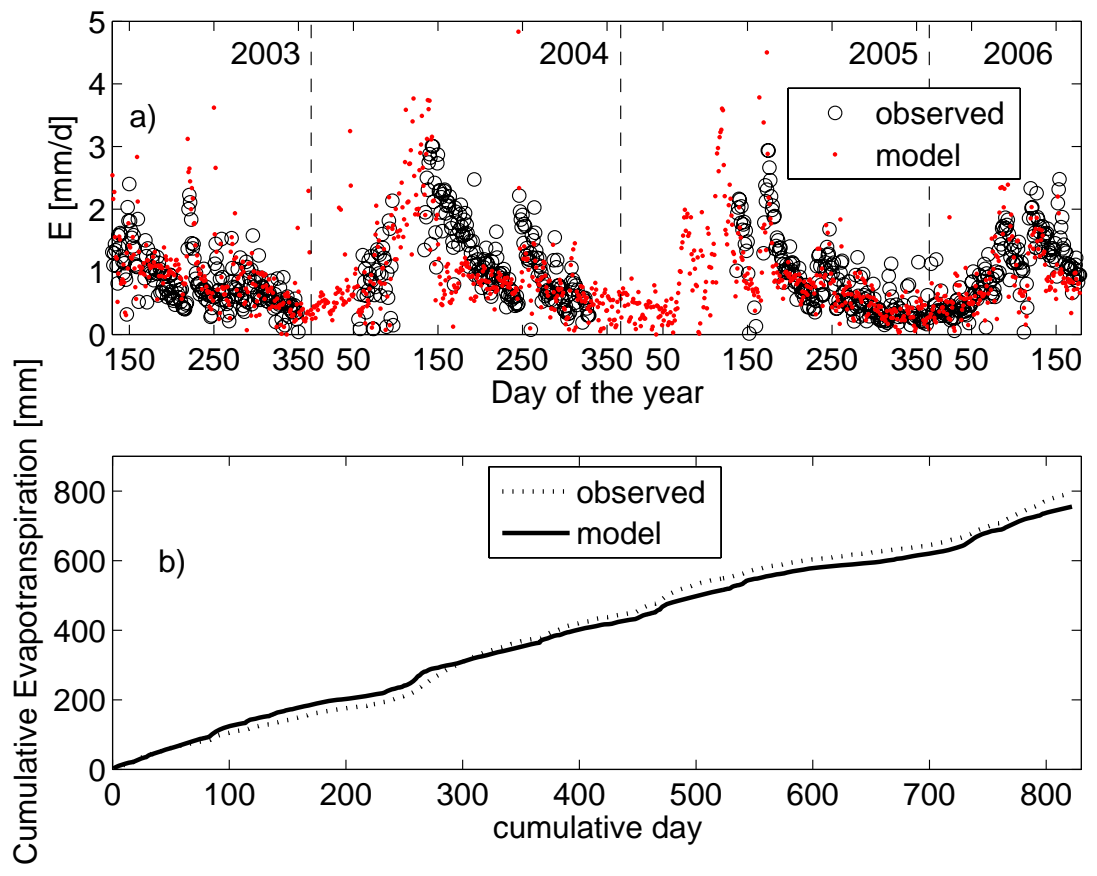

Fig. 9. (a) mean daily modeled and observed evapotranspiration rates, and (b) their cumulative values. 

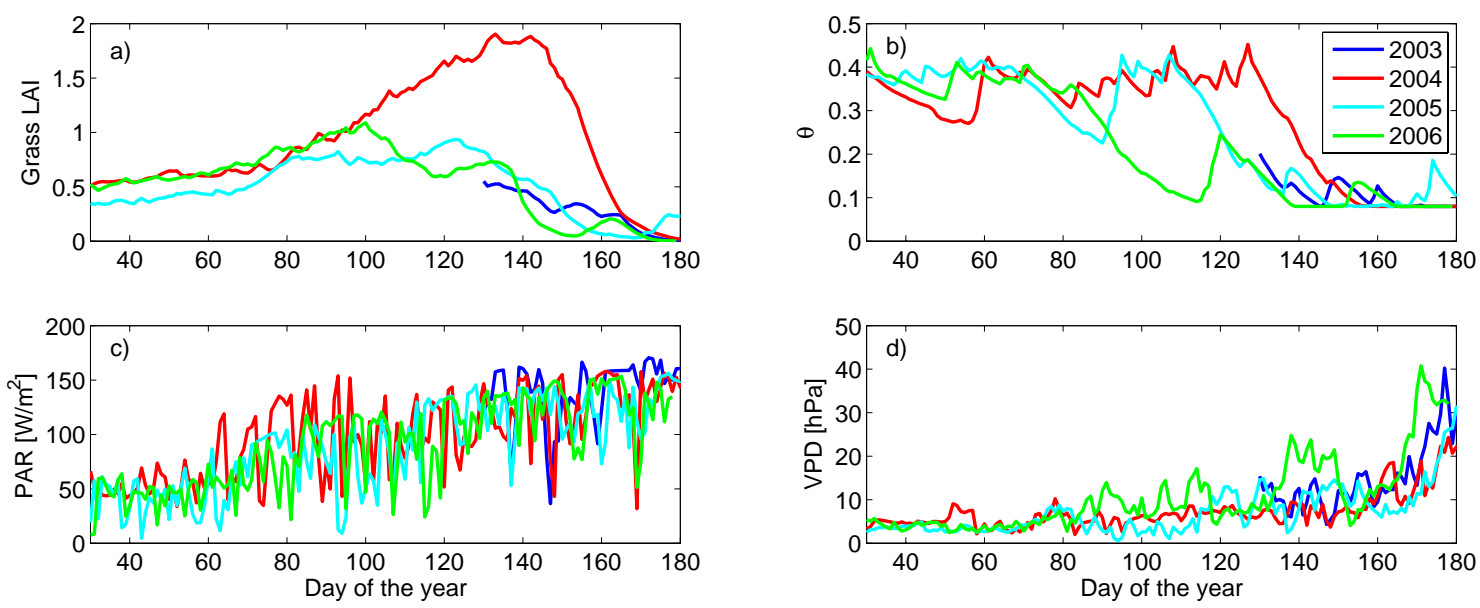

Fig. 10. Superimposed time series of (a) grass LAI simulated by VDM-LSM, (b) soil moisture simulated by VDM-LSM, (c) photosynthetically active radiation (PAR), and (d) vapor pressure deficit (VPD) during the 30-180 day period of the 2003, 2004 , 2005 and 2006 years.
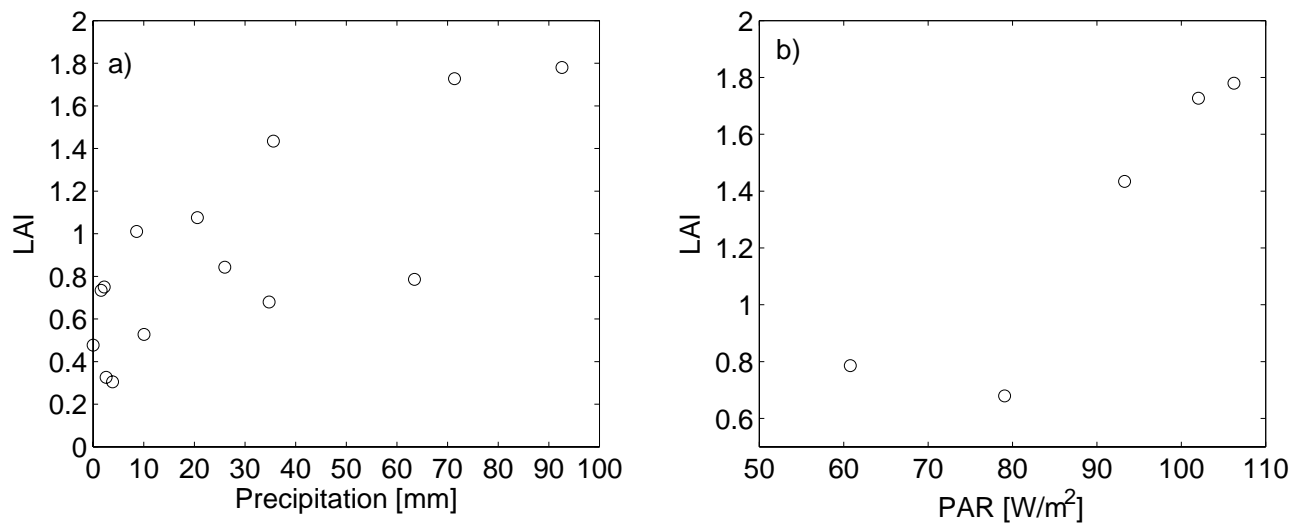

Fig. 11. (a) Averaged 15-day values of grass LAI of April and May months vs. precipitation aggregated from the previous 15-day period, and (b) vs. the averaged 15-day values of PAR for precipitation aggregated values greater than $30 \mathrm{~mm}$.

LAI is well simulated for grass as can be seen in Fig. 3. The grass model calibrated for the 2003 and 2004 years is able to simulate well the 2006 growth and the following decrease of LAI. The dynamics of the WV are predicted less well than grass but still sufficiently well for the study purposes. LAI confirms the strong tolerance of the WV species to prolonged droughts.

\subsection{Inter-annual variability of vegetation dynamics}

The different hydro-meteorological conditions of the observed years (Fig. 1 and Sect. 2.2.1) affect significantly grass vegetation dynamics, as can be well depicted by Fig. 10, where LAI grass time series during the early part (DOY 30180 , which coincides with the grass growth season in Sardinia) of each year are compared (Fig. 10a). Soil moisture dynamics, PAR and VPD time series are also compared in Fig. 10. In this case study the dynamics of grass LAI responded readily to meteorological forcing due the limited soil depth and the absence of available groundwater, which is typical in Sardinian basins. In the year 2003 after a typical January precipitation (Fig. 1a) and a wet February (DOY 32-59) the precipitation strongly decreased during the key months for the LAI growth in Sardinia (March, April and May, DOY 60-151) so that low LAI values were observed during the high irradiance period, and finally a very dry Summer occurred. During the Spring 2004 the best hydrologic conditions occurred for this site - high soil moisture until the end of the Spring season, when high values of PAR are observed - so that extremely high LAI values were predicted (Fig. 10a). In 2005 the environmental conditions were not so favorable and less grass growth was predicted. Indeed, grass growth was limited before (DOY 85-120) due to atmospheric conditions (low PAR) and after due to the soil moisture. Note that even though LAI was not measured in that year due 
to faulty instrument operation, qualitative observations (also recorded with a digital camera) confirm that there was low grass biomass in the Spring 2005. Interestingly, in the year 2006 LAI values were close to the 2004 year initially, but after the end of March (DOY 82-90) the soil moisture started to decrease limiting the grass growth and LAI could not follow the steep increase of the 2004 year.

Finally an interesting correlation between the grass LAI dynamics and precipitation during the two typical growth months, April and May, was found. In Fig. 11a the mean 15-day values of LAI versus the aggregated 15-day precipitation values time lagged by 15 days are plotted. The scatter plot shows that the grass LAI is correlated with the total precipitation of 15 days before, and a threshold value close to $\mathrm{LAI}=2$ may be identified for increasing precipitation values. For higher precipitation values soil moisture is not limiting vegetation growth, and the grass LAI variability is due to the control of other atmospheric factors. Indeed, irradiance (i.e. PAR) affects significantly LAI, as can be noted by Fig. 11b, where the mean 15-day values of LAI are plotted versus the mean 15-day values of PAR for the aggregated 15-day precipitation values greater than $30 \mathrm{~mm}$.

\section{Conclusions}

The monitored 3 hydrologic years in Orroli (Sardinia) were characterized by strong inter-annual variability of hydrometeorological conditions, such as is typical of Mediterranean semi-arid ecosystems. The inter-annual variability of atmospheric forcing significantly impacts soil moisture and vegetation dynamics, in particular during the Spring and early Summer seasons, which are key seasons for Sardinian water resources planning and management.

The yearly variability of hydro-meteorological conditions offered a wide range of conditions for testing the developed 3-component (bare soil, grass and woody vegetation) coupled VDM-LSM model. The model performed well for the whole period of observation and was able to accurately predict vegetation dynamics, soil water balance and land surface fluxes. In particular the evapotranspiration, a key term in these ecosystems, is very well predicted (to within $95 \%$ of the total observed evapotranspiration of the study period).

The typical woody vegetation species of Sardinia, representative of the broader Mediterranean water-limited region, confirm a strong tolerance to prolonged drought, such as occurred in the Summer of 2003. Even with the extreme dry conditions the WV species didn't wilt and LAI was still high $(>3)$, showing moderate changes throughout the year. This is not surprising as the typical shrubs and trees of Mediterranean water-limited ecosystems are known to be highly tolerant to water content fluctuations and are usually slow to limit their water losses (Larcher, 1995). For instance, literature values indicate that the Olea can tolerate leaf water potentials as extreme as -2 to $-3 \mathrm{MPa}$ (Lo Gullo et al.,
2003) and $-6 \mathrm{MPa}$ (Sakcali and Ozturk, 2004), and the types of Quercus in these regions can tolerate -2.5 to $-6 \mathrm{MPa}$ (Tognetti et al., 1998; Sakcali and Ozturk, 2004) without significant drop of leaf conductance, while minimal water potential values of these resistant shrubs may reach $-8 \mathrm{MPa}$ (Larcher, 1995).

Instead, the dynamics of grass LAI responded readily to meteorological forcing due the limited soil depth and the absence of available groundwater, which is typical in Sardinian basins. This allowed to find an interesting correlation between the precipitation, and the grass LAI dynamics during the Spring season, the growth season in Sardinia. The correlation was found to be high when the values of precipitation and LAI are aggregated at 15-day time intervals, and there is a sufficient time lag (15-days) between the forcing (precipitation) and the answer (LAI). The relationship between LAI and precipitation is not linear showing for the highest precipitation values a threshold value of LAI.

From an operational point of view, the proposed model is attractive since it allows to predict the response of vegetation dynamics to atmospheric forcing without prescribing phenology a priori. Although the model does need some calibration, many of the model parameters, in fact, are readily taken from literature; the parameters estimated from observations on the site are close to typical literature values, so that the model can be considered also for applications on non-instrumented fields.

\section{Appendix A}

The canopy resistance $\left(r_{c}\right)$ is used both in the LSM for the transpiration estimates using the Penman-Monteith equation and in the VDM for the photosynthesis estimate (see Table 4). Following Montaldo et al. (2005) it is estimated with a typical Jarvis (1976) approach:

$r_{c}=\frac{r_{s, \min }}{\mathrm{LAI}}\left[f_{1}(\theta) f_{2}\left(T_{a}\right) f_{3}(\mathrm{VPD})\right]^{-1}$

where $f_{1}, f_{2}$ and $f_{3}$ are stress functions of soil moisture, air temperature $\left(T_{a}\right)$, and vapor pressure deficit (VPD). The soil moisture effect is treated differently for grass and WV due to the particular resistance to water stress of WV species modeled in this Sardinian ecosystem (see Detto et al., 2006 for details on this function)

for grass : $f_{1}(\theta)=\left\{\begin{array}{lll}0, & \text { if } & \theta \leq \theta_{w p} \\ \frac{\theta-\theta_{w p}}{\theta_{\lim }-\theta_{w p},}, & \text { if } & \theta_{w p}<\theta<\theta_{\lim } \\ 1, & \text { if } & \theta \geq \theta_{\lim }\end{array}\right.$

for WV : $f_{1}(\theta)=\left\{\begin{array}{lll}-26.56 \theta^{2}+10.62 \theta, & \text { if } \quad \theta_{w p}<\theta<\theta_{\lim } \\ 1, & \text { if } \theta \geq \theta_{\lim }\end{array}\right.$

where $\theta_{\lim }$ and $\theta_{w p}$ depend on the type of vegetation (e.g. Larcher, 1995; Eagleson, 2002). The effect of temperature 
on the stomata is treated by (Nouvellon et al., 2000; Larcher, 1995)

$$
f_{2}\left(T_{a}\right)=\left\{\begin{array}{lll}
0 & \text { for } & T_{a} \leq T_{a, \text { min }} \text { and } T_{a}>T_{a, \text { max }} \\
1-\frac{T_{a, \mathrm{opp}}-T_{a}}{T_{a, \mathrm{opt}}-T_{a, \mathrm{~min}}} \text { for } & T_{a, \min }<T_{a}<T_{a, \mathrm{opt}} \\
1 & \text { for } & T_{a, \mathrm{opt}} \leq T_{a} \leq T_{a, \max }
\end{array}\right.
$$

where $T_{a, \min }, T_{a, \text { opt }}$ and $T_{a, \max }$ are characteristics of the plant types (Larcher, 1995, p. 106-113; Eagleson, 2002, p. 235241). Finally, the effect of VPD on stomata opening was modeled following Jarvis (1976)

$f_{3}=1-\omega \mathrm{VDP}$.

Acknowledgements. This work was supported by the Ministero dell'Università e della Ricerca Scientifica e tecnologica of Italy (PRIN 2006) through grants \#2006070033_002 and \#2006087458_005.

The participation of John Albertson in this research was also supported by the Duke University start-up support.

We thank Paolo Botti and Maria Antonietta Dessena of the Ente acque della Sardegna (Cagliari, Italy) for the support in the tower set-up and maintenance. We also thank Roberta Rondena for the support in the modeling preliminary efforts.

Finally, we thank Guido D'Urso and Stanislaus Schymanski for their useful comments.

Edited by: V. Iacobellis

\section{References}

Aber, J. D. and Melillo, J. M.: Terrestrial ecosystems, Academic press, 556 pp., 2001.

Albertson, J. D. and Kiely, G.: On the structure of soil moisture time series in the context of Land Surface Models, J. Hydrol., 243(1-2), 101-119, 2001.

Amthor, J. S.: The role of maintenance respiration in plant growth, Plant Cell Environ., 7, 561-569, 1984.

Arora, V.: Modeling vegetation as a dynamic component in soilvegetation-atmosphere transfer schemes and hydrological models, Rev. Geophys., 40(2), 3.1-3.26, 2002.

Arora, V. K.: Simulating energy and carbon fluxes over winter wheat using coupled land surface and terrestrial ecosystem models, Agr. Forest Meteorol., 118(1-2), 21-47, 2003.

Arora, V. K. and Boer, G. J.: A parameterization of leaf phenology for the terrestrial ecosystem component of climate models, Global Change Biol., 11(1), 39-59, 2005.

Baldocchi, D. D., Xu, L., and Kiang, N.: How plant functionaltype, weather, seasonal drought, and soil physical properties alter water and energy fluxes of an oak-grass savanna and an annual grassland, Agr. Forest Meteorol., 123, 13-39, 2004.

Brunetti, M., Maugeri, M., Nanni, T., and Navarra, A.: Droughts and estreme events in regional daily Italian precipitation series, Int. J. Climatol., 22, 543-558, 2002.
Brutsaert, W.: Evaporation into the Atmosphere, Kluwer Academic Publ., Dordrecht, Holland, 299 pp., 1982.

Calvet, J. C., Noilhan, J., Roujean, J. L., Bessemoulin, P., Cabelguenne, M., Olioso, A., and Wigneron, J. P.: An interactive vegetation SVAT model tested against data from six contrasting sites, Agr. Forest Meteorol., 92(2), 73-95, 1998.

Carlson, T. N. and Ripley, D. A.: On the relation between NDVI, fractional vegetation cover, and leaf area index, Remote Sens. Environ., 62(3), 241-252, 1997.

Cavazos, T. and Rivas, D.: Variability of extreme precipitation events in Tijuana, Mexico, Climate Res., 25(3), 229-242, 2004.

Cayrol, P., Chehbouni, A., Kergoat, L., Dedieu, G., Mordelet, P., and Nouvellon, Y.: Grassland modeling and monitoring with SPOT-4 VEGETATION instrument during the 1997-1999 SALSA experiment, Agr. Forest Meteorol., 105, 91-115, 2000.

Ceballos, A., Martinez-Fernandez, J., and Luengo-Ugidos, M. A.: Analysis of rainfall trends and dry periods on a pluviometric gradient representative of Mediterranean climate in the Duero Basin, Spain, J. Arid Environ., 58(2), 215-233, 2004.

Charles-Edwards, D. A., Doley, D., and Rimmington, G. M.: Modelling plant growth and development, Academic press, Orlando, FL, 235 pp., 1986.

Chow, V. T., Maidment, D. R., and Mays, L. W.: Applied Hydrology, McGraw-Hill Inc., 572 pp., 1988.

Clapp, R. B. and Hornberger, G. M.: Empirical equations for some hydraulic properties, Water Resour. Res., 14, 601-604, 1978.

Cox, P. M., Betts, R. A., Bunton, C. B., Essery, R. L. H., Rowntree, P. R., and Smith, J.: The impact of new land surface physics on the GCM simulation of climate and climate sensitivity, Clim. Dynam., 15(3), 183-203, 1999

Detto, M., Montaldo, N., Albertson, J. D., Mancini, M., and Katul, G.: Soil moisture and vegetation controls on evapotranspiration in a heterogeneous Mediterranean ecosystem on Sardinia, Italy, Water Resour. Res., 42(8), W08419, doi:10.1029/2005WR004693, 2006.

Eagleson, P. S.: Ecohydrology Darwinian Expression of Vegetation Form and Function, Cambridge University Press, New York, 443 pp., 2002.

Farquar, G. D., von Caemmere, S., and Berry, J. A.: A biochemical model of phosynthesis $\mathrm{CO}_{2}$ assimilation in leaves of $\mathrm{C} 3$ species, Planta, 149, 78-90, 1980.

Fernandez, J. B. G., Mora, M. R. G., Novo, F. G.: Vegetation dynamics of Mediterranean shrublands in former cultural landscape at Grazalema Mountains, South Spain, Plant Ecol., 172(1), 8394, 2004.

Gamon, J. A., Field, C. B., Goulden, M. L., Griffin, K. L, Hartley, A. E., Joel, G., Penuelas, J., and Valentini, R.: Relationships between ndvi, canopy structure, and photosynthesis in 3 californian vegetation types, Ecol. Appl., 5(1), 28-41, 1995.

Garratt, J. R.: The atmospheric boundary layer, Cambridge University Press, Cambridge, 316 pp., 1992.

Gerten, D., Schaphoff, S., Haberlandt, U., Lucht, W., and Sitch, S.: Terrestrial vegetation and water balance - hydrological evaluation of a dynamic global vegetation model, J. Hydrol., 286(1-4), 249-270, 2004.

Hanson, J. D., Skiles, J. W., and Parton, W. J.: A multi-species model for rangeland plant communities, Ecol. Model., 44, 89123, 1988. 
Haxeltine, A., Prentice, I. C., and Creswell, D. I.: A coupled carbon and water flux model to predict vegetation structure, J. Veg. Sci., 7(5), 651-666, 1996.

Jarvis, P. G., The interpretation of the variations in leaf water potential and stomatal conductance found in canopies in the field, Philos. T. Roy. Soc. B, 273, 593-610, 1976.

Kemp, P. R., Reynolds, J. F., Pachepsky, Y., and Chen, J. L.: A comparative modeling study of soil water dynamics in a desert ecosystem, Water Resour. Res., 33(1), 73-90, 1997.

Lambers, H., Chapin III, F. S., and Pons, T. L.: Plant Physiological Ecology, Spinger-Verlag, New York, 540 pp., 1998.

Larcher, W.: Physiological plant ecology, Springer, 3rd edn., 506 pp., 1995.

Lelieveld, J., Berresheim, H., Borrmann, S., et al.: Global air pollution crossroads over the Mediterranean, Science, 298(5594), 794-799, 2002.

Lo Gullo, M. A., Salleo, S., Rosso, R., and Trifilo, P.: Drought resistance of 2-year-old saplings of Mediterranean forest trees in the field: relations between water relations, hydraulics and productivity, Plant Soil, 250(2), 259-272, 2003.

Manabe, S., Milly, P. C. D., and Wetherald, R.: Simulated longterm changes in river discharge and soil moisture due to global warming, Hydrolog. Sci. J., 49(4), 625-642, 2004.

Milly, P. C. D.: An event-based simulation model of moisture and energy fluxes at a bare soil surface, Water Resour. Res., 22, 1680-1692, 1986.

Montaldo, N. and Albertson, J. D.: On The Use Of The ForceRestore SVAT Model Formulation For Stratified Soils, J. Hydrometeorol., 2(6), 571-578, 2001.

Montaldo, N., Rondena, R., Albertson, J. D., and Mancini, M.: Parsimonious Modeling of Vegetation Dynamics for Ecohydrologic Studies of Water-Limited Ecosystems, Water Resour. Res., 41(10), W10416, doi:10.1029/2005WR004094, 2005.

Moonen, A. C., Ercoli, L., Mariotti, M., and Masoni, A.: Climate change in Italy indicated by agrometeorological indices over 122 years, Agr. Forest Meteorol., 111(1), 13-27, 2002.

Mouillot, F., Rambal, S., and Lavorel, S.: A generic process-based Simulator for meditERRanean landscapes (SIERRA): design and validation exercises, Forest Ecol. Manag., 147, 75-97, 2001.

Noihlan, J. and Planton, S.: A Simple parameterization of Land Surface Processes for Meteorological Models, Mon. Weather Rev., 117, 536-549, 1989

Nouvellon, Y., Rambal, S., Lo Seen, D., Moran, M. S., Lhomme, J. P., Begue, A., Chehbouni, A. G., and Kerr, Y.: Modelling of daily fluxes of water and carbon from shortgrass steppes, Agr. Forest Meteorol., 100(2-3), 137-153, 2000.

Parlange, M. B., Albertson, J. D., Eichinger, W. E., Cahill, A. T., and Jackson, T. J.: Evaporation: Use of fast response turbulence sensors, raman lidar and passive microwave remote sensing, in: Vadose Zone Hydrology: Cutting Across Disciplines, edited by: Parlange, M. B. and Hopmans, J.W., Oxford University Press, 260-278, 1999.

Ramirez-Sanz, L., Casado, M. A., de Miguel, J. M., Castro, I., Costa, M., and Pineda, F. D.: Floristic relationship between scrubland and grassland patches in the Mediterranean landscape of the Iberian Peninsula, Plant Ecol., 149(1), 63-70, 2000.

Ramos, M. C.: Rainfall distribution patterns and their change over time in a Mediterranean area, Theor. Appl. Climatol., 69(3-4), 163-170, 2001.
Reynolds, J. F., Kemp, P. R., and Tenhunen, J. D.: Effects of longterm rainfall variability on evapotranspiration and soil water distribution in the Chihuahuan Desert: A modeling analysis, Plant Ecol., 150(1-2), 145-159, 2000.

Richards, J. A.: Remote Sensing Digital Image Analysis, SpringerVerlag, Berlin, 439 pp,, 1999.

Sakcali, M. S. and Ozturk, M.: Eco-physiological behaviour of some mediterranean plants ad suitable candidates of degraded areas, J. Arid Environ., 57(2), 141-153, 2004.

Sanchez, E., Gaertner, M. A., Gallardo, C., Padorno, E., Arribas, A., and Castro, M.: Impacts of a change in vegetation description on simulated European summer present-day and future climates, Clim. Dynam., 29(2-3), 319-332, 2007.

Scanlon, T. M., Albertson, J. D., Caylor, K. K., and Williams, C. A. Determining land surface fractional cover from NDVI and rainfall time series for a savanna ecosystem, Remote Sens. Environ., 82(2-3), 376-388, 2002.

Scholes, R. J. and Archer, S. R.: Tree-grass interactions in savannas, Annu. Rev. Ecol. Syst., 28, 517-544, 1997.

Shuttleworth, W. J. and Wallace, J. S.: Evaporation from sparse crops - an energy combination theory, Q. J. Roy. Meteor. Soc., 111, 839-855, 1985.

Sivapalan, M., Beven, K. and Wood, E. F.: On hydrologic similarity, 2: A scaled model of storm runoff production, Water Resour. Res., 23, 2266-2278, 1987.

Tognetti, R., Longobucco, A., Miglietta, F., and Raschi, A.: Transpiration and stomatal behaviour of Quercus ilex plants during the summer in a Mediterranean carbon dioxide spring, Plant Cell Environ., 21(6), 613-622, 1998.

Vanrheenen, N. T., Wood, A. W., Palmer, R. N., and Lettenmaier, D. P.: Potential implications of PCM climate change scenarios for Sacramento-San Joaquin River Basin hydrology and water resources, Climatic Change, 62(1-3), 257-281, 2004

Ventura, F., Pisa, P. R., and Ardizzoni, E.: Temperature and precipitation trends in Bologna (Italy) from 1952 to 1999, Atmos. Res., 61(3), 203-214, 2002.

Vermote E. F., Tanre, D., Deuze, J. L., Herman, M., and Morcrette, J. J.: Second Simulation of the Satellite Signal in the Solar Spectrum, 6S: An overview, IEEE T. Geosci. Remote, 35(3), 675686, 1997.

Vertessy, R. A., Hatton, T. J., Benyon, R. G., and Dawes, W. R.: Long-term growth and water balance predictions for a mountain ash (Eucalyptus regnans) forest catchment subject to clearfelling and regeneration, Tree Physiol., 16(1-2), 221-232, 1996.

Walker, B. H. and Langridge, J. L.: Modelling plant and soil water dynamics in semi-arid ecosystems with limited site data, Ecol. Model., 87(1-3), 153-167, 1996.

Webb, E. K., Pearman, G. I., and Leuning, R.: Correction of Flux Measurements for Density Effects Due to Heat and Water-Vapor Transfer, Q. J. Roy. Meteor. Soc., 106(447), 85-100, 1980.

Williams, C. A. and Albertson, J. D.: Soil moisture controls on canopy-scale water and carbon fluxes in an African savanna, Water Resour. Res., 40(9), W09302, doi:10.1029/2004WR003208, 2004. 